\title{
Small and Medium Enterprises: Management of Intellectual Property Rights in Nigeria
}

\section{Carl Osunde*}

Dean of Studies, Onitsha Business School, Anambra State, Nigeria

\begin{abstract}
It is important that SMEs assess their intellectual property and develop policies on the management of intellectual property rights to effectively and efficiently maximise the use of intellectual property rights in relation to threats from competitors. Managers sometimes use their IP rights to suppress other competitors from engaging in the production and distribution of products covered by the IP rights, thereby having the monopolistic power to raise prices of the products to increase profits. This study examines four ways managers at SMEs can adequately manage intellectual property rights which include (1) acquisition (2) exploitation (3) monitoring and (4) enforcement. One of the key conclusions of this study is that Managers should continuously check IP databases to determine the status of their intellectual property rights and whether there is any infringement on their intellectual property rights. Infringement of intellectual property rights can result to huge financial losses as a result of mass production, cheap and substandard copies of original products.
\end{abstract}

Keywords: Intellectual property; Intellectual property rights; Small and medium enterprises; Infringement

\section{Introduction}

Small and medium enterprises (SMEs) intellectual property rights require proper management since intellectual property rights are valuable asset to SMEs [1].

Innovative firms can achieve high returns and secure their investments through the proper management of intellectual property rights [2].

Owners of SMEs must continuously evaluate their intellectual property rights assets through consultations with managers and lawyers and develop policies on the management of intellectual property rights [3].

Managers at SMEs in Nigeria do not develop enough strategies to maximise the use of intellectual property rights in relation to competitors [4].

Managers sometimes use their IP rights to suppress other competitors from engaging in the production and distribution of products covered by their IP rights, in the hope that the business enterprise that holds the IP rights will be the dominant producer in the market, thereby having the power to raise prices of the products to increase profits, this is monopolistic in nature designed to prevent competitors in the market from engaging in the production, distribution and sales of products covered by their IPRs.

Suppressing other firms through legal actions as a result of ownership of IP rights is not the only viable option to manage intellectual property rights. Other options with regard to management of intellectual property rights are: sale, collaboration and franchising of the intellectual property rights [5].

The intellectual property rights can be further exploited by granting licenses to competitors which can lead to collaborations with competitors, suppliers and customers.

This study examines four ways in which managers at SMEs can adequately manage intellectual property rights, these include (1) acquisition (2) exploitation (3) monitoring and (4) enforcement.

\section{Acquisition}

SMEs need to develop strategies for acquision of IPRs. In Europe, patents are the most sought after IPRs for the protection of intellectual property of SMEs. About 60,000 patents are filed annually by SMEs. The European Patent Office reports that 178,000 applications are filed for the protection of IP [6].

\section{Exploitation}

Exploitation in this context refers to use of intellectual property rights acquired by small and medium enterprises for their economic benefits and putting such rights into commercial use in the form of licensing revenues, franchise and sale of the intellectual property rights to raise capital for the business venture.

\section{Monitoring}

Pirated DVDs and Cds, copying of live premiership matches without permission, sales of pirated products including textbooks litter the Nigerian market, even in advanced countries in Europe and America piracy continue to be a plague that negatively affects holders of intellectual property rights.

Owners of small and medium enterprises invest billions of dollars annually to finance inventions and acquire intellectual property rights.

Counterfeiters seek to gain financially from inventions, published works and trademarks. These counterfeiters have devised various means to dodge law enforcement officers who often close down their shops and prosecute these counterfeiters in law courts. However, Counterfeiters

*Corresponding author: Carl Osunde, Dean of Studies, Onitsha Business School, Anambra State, Nigeria, Tel: +2347065012259; E-mail: osundecj@gmail.com

Received February 01, 2017; Accepted March 08, 2017; Published March 16, 2017

Citation: Osunde C (2017) Small and Medium Enterprises: Management of Intellectual Property Rights in Nigeria. Intel Prop Rights. 5: 180. doi: 10.4172/23754516.1000180

Copyright: (C) 2017 Osunde C. This is an open-access article distributed under the terms of the Creative Commons Attribution License, which permits unrestricted use, distribution, and reproduction in any medium, provided the original author and source are credited. 
have moved their illegal trade online or through e-commerce websites where they can hide using fake names to sell their pirated goods without detection.

Owners of intellectual property rights apart from informing the authorities to rigorously protect their licenses where there is an infringement of their intellectual property rights by individuals or other organisations should seek to monitor the internet for infringement on their intellectual property rights and enforce the shutting down of these websites through various platforms dedicated to shut down websites that infringed on the intellectual property rights of others [7].

\section{Enforcement}

In Nigeria, the enforcement of intellectual property rights lies with governmental agencies that have the power to investigate, arrest and prosecute counterfeiters and those who illegally copy the published works or infringe on the intellectual property rights of others including small and medium enterprises [8].

During 2016, there were a number of arrests in major cities of Nigeria by law enforcement agencies such as the Nigerian Copyright Commission (NCC) and Nigerian Police concerning the illegal copying and distribution of live premiership matches from England by individuals to homes after charging minimal monthly fees without permission from the original license owners. The license to broadcast premiership matches in Nigeria belongs to a cable company, DSTV which is a South African company that operates in Nigeria and many African countries.

Therefore, an efficient and effective enforcement of intellectual property rights will enhance investments in innovative products and ensure that owners of small and medium enterprises benefit from their intellectual property rights. Infringement of intellectual property rights can result to huge financial losses as a result of mass production, cheap and substandard copies of original products [9].

\section{Intellectual Property Disputes in Nigeria: Procter and Gamble versus Global Soap and Detergent Industries Ltd}

In 1969, Proctor \& Gamble (P\&G) registered a trademark in Nigeria known as 'ARIEL'. In 1998, P\&G found out that Global Soap and Detergent Industries Ltd had registered 'ARIEL and Atomium Device' as their trademark. P\&G filed for infringement of their trademark in a Nigerian law court against Global Soap and Detergent Industries Ltd.

At the Federal High Court in Nigeria, the court rejected P\&G entitlement to the exclusive use of the trademark 'ARIEL' stating that P\&G had lost the intellectual property right due to non-use and that the trademark had become generic.

P\&G appealed the judgement of the Federal High Court in Nigeria, on January $24^{\text {th }}, 2012$, the Court of Appeal presided by Justice Helen Ogunwumji overturned the decisions of the Federal High Court stating that it is not known to law to expunge a trademark for non-use. The court affirmed that a registered trademark can become generic if the consuming public inappropriately use the trademark in a way that the trademark becomes known as the name of the product in the public domain [10].

\section{Managerial Implications}

1. Managers as a first step to manage the intellectual property rights of SMEs should identify the IP owned and currently in use by the enterprise.

2. Managers should frequently check databases to confirm the ownership of their IP, assignments of the IP if acquired from third parties or other sources. This will guard against infringement of the IP by competitors.

3. Managers at SMEs should regularly review agreements, contracts, litigations or disputes of IP and to ensure that the IP are still valid if fees for renewal of the IPRs are required.

4. Managers should continually develop strategies to efficiently and effectively manage the IPRs of SMEs.

\section{Conclusion}

Enforcement of intellectual property rights lies with agencies that can ensure that the law takes its course if there are infringements of intellectual property rights such as counterfeiting, copying and illegal production of the published works of artists and authors.

Managers should strive to develop strategies to effectively and efficiently manage IP of SMEs such ensuring they keep updated information of the status of the IP owned and check databases whether there is any infringement on their intellectual property rights. Infringement of intellectual property rights can result to huge financial losses as a result of mass production, cheap and substandard copies of original products.

There are four aspects of intellectual property rights where managers can manage in SMEs to create value for the enterprise; these are (1) acquisition (2) exploitation (3) monitoring and (4) enforcement.

\section{References}

1. Fisher III WW, Oberholzer-Gee F (2013) Strategic Management of Intellectual Property: An integrated Approach. California Management Review 55: 157-183.

2. Graham SJH, Sichelman TM (2008) Why Do Start Ups Patent? Berkeley Technology Law Journal 23: 1063-1097.

3. Caseroni F, Piccaluga A (2013) Operational Challenges and ST's Proposed Solutions to Improve Collaboration Between IP and R\&D in Innovation Processes. California Management Review 4: 55.

4. Katz M, Shapiro C (2001) R\& D Rivalry with Licensing or Imitation. American Economic Review 77: 402

5. Anand B, Galetovic A (2004) How Market Smarts Can Protect Property Rights. Harvard Business Review 82: 73-79.

6. European Patent Academy (2007) ip4inno consortium report.

7. Zittrain J (2008) The Future of Internet - And How to Stop it. New Haven, CT: Yale University Press 1: 2.

8. Fisher W (2010) Implications for Law of User Innovation. Minnesota Law Review 94: 102-114.

9. Harris LTC (2005) The enforcement of intellectual property rights: A case book 135: 250.

10. Osunde C (2014) Managing the Risks of Business Ethics in a Nigerian Environment, Vol. 2(2). pp. 33-38. 